\title{
WNK2 Gene
}

National Cancer Institute

\section{Source}

National Cancer Institute. WNK2 Gene. NCI Thesaurus. Code C143106.

This gene plays a role in electrolyte homeostasis, cell signaling, cell survival, and cellular proliferation. 